\title{
The Reception of Peirce in Spain and the Spanish Speaking Countries
}

Sara Barrena and Jaime Nubiola

\section{OpenEdition}

1 Journals

Electronic version

URL: http://journals.openedition.org/ejpap/491

DOI: 10.4000/ejpap.491

ISSN: 2036-4091

Publisher

Associazione Pragma

\section{Electronic reference}

Sara Barrena and Jaime Nubiola, «The Reception of Peirce in Spain and the Spanish Speaking Countries », European Journal of Pragmatism and American Philosophy [Online], VI-1 | 2014, Online since 08 July 2014, connection on 17 March 2020. URL : http://journals.openedition.org/ejpap/491 ; DOI : https://doi.org/10.4000/ejpap.491

This text was automatically generated on 17 March 2020.

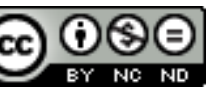

Author retains copyright and grants the European Journal of Pragmatism and American Philosophy right of first publication with the work simultaneously licensed under a Creative Commons AttributionNonCommercial-NoDerivatives 4.0 International License. 


\title{
The Reception of Peirce in Spain and the Spanish Speaking Countries
}

\author{
Sara Barrena and Jaime Nubiola
}

\section{AUTHOR'S NOTE}

We are grateful to Giovanni Maddalena for his invitation to take part in this special issue and to Erik Norvelle for his translation into English.

1 A surprising fact about the Hispanic philosophical historiography ${ }^{1}$ of the 20th century is its almost complete ignorance of the American philosophical tradition. This disconnect is even more surprising when one takes into account the striking affinities between the topics and problems treated by the most relevant Hispanic thinkers (Unamuno, Ortega, Vaz Ferreira, Ferrater Mora, Xirau) and the central questions raised in the most important native current of American thought in the late 19th and 20th centuries, pragmatism.

2 In recent years there has been a resurgence of pragmatist philosophy in contemporary culture, which is producing a deep renovation and transformation. One of the important features of this process is precisely the recuperation and improved understanding of the thought of Charles S. Peirce, who offers suggestions for dealing with some of the most persistent problems in contemporary philosophy, and who in addition can help us to reassume our responsibilities as philosophers, responsibilities that a good part of the philosophy of the 20th century had renounced. We can confidently say, as will be clear from what follows, that Spain and the Latin American countries are playing an important role in this increased understanding and diffusion of Peircean thought throughout the world. 


\section{The Historic Lack of Knowledge about Peirce in the Spanish-Speaking Countries}

3 During the first half of the 20th century the figure and thought of Charles S. Peirce were practically unknown in the Spanish-speaking countries. This ignorance of Peirce and of pragmatism in general in the world of Hispanic philosophy can be attributed to several causes. First, Peirce's works are not easily accessible, even in English. The difficulty of gaining direct access to his works has been one of the causes of Peirce's remaining unstudied until recently. This difficulty has been even greater in Europe, since it has only been for a quarter century or so that anthologies with reasonable coverage have been available in Italian, French and German (Castañares 1992, 215). Another likely cause of this disconnection of Hispanic philosophy from the American tradition is a mutual lack of understanding at the cultural level: the sociological factors that have separated these two cultures over the course of the 20th century have impeded the ability to recognize their deeper affinity.

4 Pragmatism is a response, on the basis of both scientific and lived experience, to the problem typical of modern Cartesianism concerning the rift between rational thought and creative vitality. The Spanish philosophers Unamuno, Ortega, and d'Ors, in a manner entirely analogous to that of the Italians Papini, Vailati, and Calderoni, were responding to this shared problem in a strikingly similar way to that of the Americans. Nevertheless, the recognition of this "community" has come quite late, perhaps due to the permanent pretension to originality that is typical of the Hispanic tradition, and due to the provincialism that is characteristic of the American tradition.

As Vericat has noted, the reception of Peirce in the Hispanic world was a bit phantasmagorical, in the sense that his importance was openly recognized, but hardly anyone knew the contents of his philosophical works (Vericat 1988, 15). This began to change towards the end of the 1970s, when there was a sudden flurry of interest in the American scientist and philosopher, as witnessed to by the first translations performed in Argentina. This interest has grown strongly over the last four decades, as is indicated by both the numerous translations that have appeared during this time, thus making a relevant part of Peirce's vast writings available, as well as by the growing number of books and research projects that have appeared concerning pragmatism and its principal thinkers.

\section{The Rise of Peircean Thought}

"Most people have never heard of him, but they will," wrote the American novelist Walker Percy (Percy 1996, 1143) in reference to Charles S. Peirce, and it seems as though that prophecy is beginning to come true. Indeed, in recent years the figure of Peirce has acquired an increasing relevance in numerous areas of knowledge (Fisch 1980; 1981), and his influence continues to grow: in astronomy, metrology, geodesy, mathematics, logic, philosophy, theory and history of science, semiotics, linguistics, econometrics, and psychology. Scholars throughout the Spanish-speaking world are coming to recognize Peirce importance.

7 In order to understand the new interest in Peirce in Spanish, we can point first of all to the influence of Umberto Eco, Jürgen Habermas, and Karl-Otto Apel, as well as to the 
slow closing of distances of Hispanic philosophy to the world of American academic philosophy in recent years. The recent resurgence of pragmatism, together with these two other factors, has been decisive for showing the Hispanic world that Peirce was, or rather is, important for a correct understanding of our contemporary culture. Even more, from a historical point of view, the study of the roots of Peirce's semiotics in the Hispanic Scholastic tradition - as exemplified by Beuchot (Beuchot 1991) and Deely (Deely 1995) - and the strange affinity between pragmatist philosophy and Hispanic thought, have together helped to break down the traditional isolation that has long affected and impoverished the Hispanic philosophical tradition.

In order to better understand how this new interest in Peirce studies has arisen in the Spanish-speaking world, we will next focus on two key phenomena:

\subsection{Translations}

The first translation of Peirce into Spanish was of a brief article, "Irregularidades en las oscilaciones del péndulo," published by the journal of Barcelona Crónica Científica on October 25, 1883. It was a translation of Peirce's observations from the previous year published in The American Journal of Science. The second reference in the Spanish bibliography is an article on Peirce published in 1892 in El Progreso Matemático of Zaragoza by the mathematician Ventura Reyes Prósper, who had corresponded with him. It is highly significant that the first notice that the Hispanic world took of Peirce regarded his work as a scientist. In the realm of philosophy the first references to Peirce were those by Marcelino Arnáiz, in his "Pragmatism and Humanism" of 1907, those of Eugenio d'Ors - who had come to know the American pragmatism of James and Peirce during his stay in Paris in 1906-07 - in his newspaper column, and the 60-pages volume El pragmatismo, by José María Izquierdo y Martínez, published by the Ateneo of Seville in March of 1910.

10 In Latin America, the first encounter with pragmatism was also through James - for example, in the works of the philosopher Coriolano Alberini (Argentina), Carlos Vaz Ferreira (Uruguay) and particularly Pedro S. Zulen (Perú), who stayed at Harvard and prepared there a doctoral dissertation that was published with the title Del Neohegelianismo al Neorrealismo (Lima, 1924). The book is a study about the origins of American philosophy from the School of St. Louis, through the neo-Hegelianism of Josiah Royce, and including Peirce, pragmatism and neo-realism. The section on Peirce (26-33) is well informed and is a personal reflection about Peirce's philosophy relating it to James' conceptions.

11 The first compilations of Peirce's writings were published in Argentina thanks to the work of the publishing house Editorial Aguilar (Buenos Aires). This project produced two translations: Deducción, inducción e hipótesis, in 1970, and Mi alegato en favor del pragmatismo, in 1971. Each of these books brought together two articles published by Peirce in Popular Science Monthly between 1877 and 1878 (vol. XII-XIII), and which are particularly important for understanding the thought of Peirce in his earliest epoch. In these articles one can see how he elaborates his theory of abductive inference - which he still terms "hypothesis" - as well as certain basic aspects of what he understood pragmatism to be. Both works are preceded by introductions by Juan Martín RuizWerner, which, despite being improvable in certain respects, had the merit of making it 
possible for Spanish-speaking readers to get to know an author that previously was totally unknown to them (Castañares 1992, 216).

In 1978 the same publisher brought out Lecciones sobre el pragmatismo. This is a more extensive work that brings together Peirce's lectures at the Lowell Institute between March and May of 1903. In these lectures Peirce presented the basic ideas for an outline of pragmatism that would be substantially different from that of William James and others. The preparation of this edition was carried out by Dalmacio Negro Pavón. As Castañares wrote: "Seen as a whole, the works published by Aguilar in Argentina were intended to allow the reader to get to know the pragmatism of Peirce with a certain rigor, and full-length works were chosen for this purpose." (Castañares 1992, 216.)

In 1988 in Spain there appeared a translation by Pilar Castrillo, entitled Escritos lógicos (Madrid, Alianza), which brought together eleven articles by Peirce that were representative of his contributions to logic, and the edition by José Vericat entitled $\mathrm{El}$ hombre, un signo (El pragmatismo de Peirce) (Barcelona, Crítica), also appeared, boasting an ample introduction and abundant notes and bibliographical information.

In this section about translations we would like to highlight the work undertaken by the Grupo de Estudios Peirceanos of the Universidad de Navarra. Begun in 1994 with the purpose of promoting the study of Peirce's works, especially in Spain and other Spanish-speaking countries, this Group has translated a vast amount of material, now available on its website: more than 100 translated texts by Peirce himself, a great deal of his correspondence translated and annotated, ${ }^{2}$ and the publication of several printed volumes containing texts by Peirce in Spanish. Among these volumes we would like to underline several of particular importance: Un argumento olvidado en favor de la realidad de Dios (Pamplona, Cuadernos de Anuario Filosófico, 1996); La lógica considerada como semiótica. El índice del pensamiento peirceano (Madrid, Biblioteca Nueva, 2007); El pragmatismo (Madrid, Encuentro, 2008); El amor evolutivo y otros ensayos sobre ciencia $y$ religión (Barcelona, Marbot, 2010).

Another important translation has been that of the compilation of Peirce's texts edited by Nathan Houser and Christian Kloesel: The Essential Peirce. Selected Philosophical Writings (Indiana University Press, 1992-98). The two volumes of this compilation were published in Spanish in Mexico with the title Obra filosófica reunida (Fondo de Cultura Económica, 2012). The translation into Spanish of such an important and highly cited selection of Peircean texts has been a major step forward in the study and diffusion of the thought of Peirce in Spain and in the Spanish-speaking world.

\subsection{The Influence of the Internet}

The rise of the Internet was a fundamental landmark in the reception of Peirce in Spain and Latin America, since it constitutes a powerful tool for studying this author in Spanish. The enormous physical distance that separates Spain from the rest of the Spanish-speaking countries can now be overcome thanks to the new computer technologies. The website of the Grupo de Estudios Peirceanos (unav.es/gep/) has been a tremendously important tool for this purpose, not only because it provides translations of Peirce's texts, but also because it has helped to create a research community which, following the scientific method propounded by Peirce himself, permits undertaking studies of his thought and advancing towards the truth, which can only be achieved by the work of the entire community. 

visits annually, enables to put the bibliography and other instruments necessary for undertaking research about Peirce into the hands of all interested researchers. It is also an invitation to think and to participate, and in this way the Group has been able to give visibility to scholars interested in pragmatism, contributing to the creation of important groups of researchers in numerous countries, including Argentina, Chile, Colombia, México and Panamá. There are also scholars undertaking research in Peirce in other countries, although in a more dispersed way: Cuba, Perú, Puerto Rico and Venezuela. Within this network of Hispanic Peirce scholars we can highlight the important work of Fernando Zalamea and his Centro de Sistemática Peirceana at the Universidad Nacional de Colombia (acervopeirceano.org/) and of Mauricio Beuchot and Edgar Sandoval in México. Spanish we would also like draw attention to the newsletter that the Grupo de Estudios Peirceanos publishes, which is sent free every two weeks to more than 300 subscribers, bringing some of the most relevant news concerning Peirce studies and pragmatism to people around the world.

\section{Peirce and the Hispanic World: Peirce Studies Today}

19 The connections between Peirce and Spain - which until recently seemed very meager - have been studied in depth, and the data collected suggest that, although Peirce and Spain belong to different worlds, there are many more connections than those that one might initially have expected. In this regard the book published in 2006 by Jaime Nubiola and Fernando Zalamea, Peirce y el mundo hispánico. Lo que C. S. Peirce dijo sobre España y lo que el mundo hispánico ha dicho sobre Peirce (Pamplona, Eunsa) is especially relevant (See also Nubiola 2012). This book not only brings together all the available data about what Peirce wrote about Spain, but also provides a valuable critical review of almost everything that the Hispanic world wrote about Peirce between 1883 and 2000. This global view on the relations between Peirce and the Hispanic countries contributes, as the authors suggest, to creating a community that has a strong capacity for critical contrast and which can therefore grow in a healthy way.

It is also important to emphasize the important role - on many occasions carried out with great dedication and with insufficient means - that scholars from certain Latin American countries have played in the reception of Peirce. Argentina, in particular, occupies a privileged place in the reception of Peirce's thought in the Hispanic world. The primary cause of this preeminence is because, as we have already mentioned, it was in Argentina in the 1970s that the first translations of Peirce in Spanish were published. Nevertheless, the relevance is not merely historical: even today there is a great interest in pragmatist thought in Argentina. As an indication of this interest we can mention the creation of a Grupo de Estudios Peirceanos in Argentina, as well as the biannual scholarly conference on Peirce that has been held in the Academy of Sciences of Buenos Aires for a decade with great success (unav.es/gep/ JornadasPeirceArgentina.html).

21 As Wenceslao Castañares has written, Peirce's writings are full of traps for those who approach them without any preparation or due caution. Even those who repeatedly return to his works end up suffering an unpleasant sensation: the doubt that their 
interpretation is not correct or coherent. This is why it is so necessary to maintain a continual practice of reading as well as dialogue with others in order to overcome the constant difficulties that arise (Castañares 1992, 224). The Hispanic community that has formed around Peirce is essential for this purpose. With more than 100 dissertations and monographs published in recent years on Peirce and pragmatism, Hispanic scholars have much to say within the context of the international community of Peirce researchers. Increasing and bettering the diffusion of Peircean scholarship in Spanish makes it possible for Hispanic researchers, standing on the results of their predecessors, to advance like true "dwarfs standing on the shoulders of giants." In the purest Peircean spirit the Hispanic community must continue to build on our shared fund of knowledge, thereby alleviating to the degree possible the heavy burdens that each of us takes on as we walk this path together (Nubiola - Zalamea 2006, 11).

\section{BIBLIOGRAPHY}

ARNÁIZ M., (1906), “Pragmatismo y Humanismo,” Cultura Española, 6 (1907), 616-27, (unav.es/gep/ArticulosOnLineEspanolAnteriores.html).

BEUснот M., (1991), “La filosofía escolástica en los orígenes de la semiótica de Peirce," Analogía 5

(2), 155-66.

CASTAÑARES W., (1992), "Peirce en España; panorama bibliográfico," Signa 1, 215-24, (cervantesvirtual.com/obra-visor/n-1-ao-1992/html/).

DEELY J., (1995), “Common Sources for the Semiotic of Charles Peirce and John Poinsot," Review of Metaphysics 48 (3), 539-66, (jstor.org/stable/20129719).

FISCH M., (1980-81), “The Range of Peirce's Relevance,” The Monist 63 (1980), 269-76; 64 (1981), 123-41.

MUÑoz DELGADo V., (1980), “Notas para la historia de la lógica durante la Segunda República Española (1931-39)," Religión y Cultura 26, 909-11.

NICOL E., (1961), El problema de la filosofía hispánica, Madrid, Tecnos.

NUBiola J. \& F. ZALAMEA, (2006), Peirce y el mundo hispánico. Lo que C. S. Peirce dijo sobre España y lo que el mundo hispánico ha dicho sobre Peirce, Pamplona, Eunsa.

NUBIOLA J., (2012), “New Developments Regarding Peirce's Reception in the Hispanic World,” InterAmerican Journal of Philosophy 3 (1), 86-94,

(ijp.tamu.edu/journal/sites/default/files/papers/Nubiola.pdf).

PERCY W., (1996), “La criatura dividida,” Anuario Filosófico 29 (3), 1135-57 (hdl.handle.net/ 10171/529).

VERICAT J., (1988), “Introducción,” in C. S. Peirce, El hombre, un signo: (El pragmatismo de Peirce), Barcelona, Crítica Editorial. 


\section{NOTES}

1. We use the term "Hispanic philosophy" to refer to that produced in Spain and Latin America. The term was originally coined in 1961 by the Catalan philosopher in exile Eduardo Nicol

2. Currently, the Grupo de Estudios Peirceanos is developing an in-depth study of Peirce's correspondence during his five journeys to Europe. This project is financed by the PIUNA of the Universidad de Navarra (2007-2009, 2012-2014) and by the Spanish Ministry of Science and Research (FFI2011-24340).

\section{AUTHORS}

\section{SARA BARRENA}

Universidad de Navarra, Spain

sbarrena[at]unav.es

\section{JAIME NUBIOLA}

Universidad de Navarra, Spain

jnubiola[at]unav.es 